\title{
Design \& Analysis of Spaceframe Chassis for FSAE Vehicle
}

\author{
${ }^{1}$ Shobhit Agarwal, ${ }^{2}$ Prashant Awasthi, ${ }^{3}$ Tarun Saatyaki, ${ }^{4}$ Mukul Kushwaha, ${ }^{5}$ Vishal Jaiswal \\ Under guidance of Prof. Sambasivam Anivel \& Prof. M.Maniraj \\ School of Mechanical Engineering, Galgotias University \\ Gr. Noida, India
}

\begin{abstract}
This research paper aims at designing and analyzing chassis of Formula SAE car for Automantra Racing, SAE team of Galgotias University. Chassis is a base frame of a vehicle. The frame has spaces for the components to be fixed into the vehicle. FSAE (Formula Society of Automotive Engineers) is an organization which organizes formula student events in all over the world. The Formula style chassis are of different types Monocoque and space frame. But Space Frame Chassis is easy to fabricate and to attain structural rigidity most of the students prefers Space Frame. According to guidelines of Formula student events the chassis should be made up of AISI 4130 Chromoly Steel, this material consists of Alloy of Chromium and Molybdenum, so it has light weight as well as high strength. Analytical calculations are done based on standard results to get maximum strength with minimum possible weight. Software tools used to design, and analysis are Solidworks (for CAD modeling) \& Ansys(for FEA).
\end{abstract}

\section{Keywords-FSAE, Chassis, Frame, Solidworks, Ansys, FEA}

\section{INTRODUCTION}

Depending upon structure the chassis should have resistance to deformation that is stiffness. The space frame chassis that we made is of tubes and having roll cage structure. The steel tubes are of AISI 4130 Chromoly having light weight and high strength[1]. For this present work the optimal range of torsional rigidity is obtained by making the frame as light as possible by adjusting the size and location of the structural members. The paper focuses on the different configuration and actions of the chassis used in the FSAE competition when the chassis is used with front impact, side impact and torsional stiffness by following the rules of the Formula SAE competition[2]. Figure. 1 shows the frame of the chassis built according to the FSAE rulebook. First concept is based on AR20 chassis, the new Automantra Racing team, Galgotias University's official formula student combustion team.

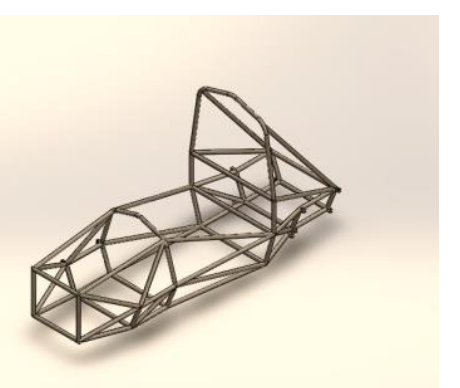

Figure 1: Chassis for AR20

\section{LITERATURE REVIEW}

Patel Vijaykumar V, Prof. R. I. Patel, Mechanical Department, Government Engineering College, Dahod, Gujarat, India [1] gives us information on various calculations for stress analysis, load values \& deflections. This paper also helps us in reducing weight with maximum strength.

Erica R.H. Fuchs, Frank R. Field, Richard Roth, Randolph E. Kirchain, Massachusetts Institute of Technology, 77 Massachusetts Avenue, E38-104, Cambridge, MA 02139, USA[2], gives us information regarding calculations of effects of load on various materials material selection for our this year chassis.

University of Southern Queensland Faculty of Engineering and Surveying[3], report give us a detailed report on designing a space frame with load transfer calculations using

$$
\text { Load transfer }=\frac{\text { weight } * \text { accelaration } * \text { CG height }}{\text { Trackwidth or wheel base }}
$$

From the equation, it is obvious that longitudinal load transfer can be reduced by lengthening the wheelbase, lowering the centre of gravity, adding lightness (Chapman) or softening initial acceleration. (This assumes, naturally, that the chassis is strong enough to transmit these forces and not simply flex all out of shape). Under braking excessive load transfer can cause many problems - unloading the rear tires (and reducing their braking ability) and loading up the front tires (and uses up some of the suspension travel - allowing possible bottoming of parts of the vehicle).

The basic lateral load transfer (LLT) equation is:

$$
\mathbf{L L T}=\frac{\text { (lat accel } \mathrm{x} \text { force down at axle } \mathrm{x} \text { cg height) }}{\text { Track }}
$$

\section{METHODOLOGY}

The first step towards manufacturing the chassis is to fully read and understand the rules and regulations[3]. Because driver safety is critical, the following rules and regulations provide required safety information and ideas. In the world of engineering, designing a race car is basically a big task, and these rules give us the right way to move forward[4].

Components and Parts of the chassis: 
A. Primary Structure:

The rule book defines following frame members as the primary structure of the chassis:

1. Front Bulkhead

2. Main Hoop

3. Front hoop

4. Roll hoop Bracings

5. Front Bulkhead supports

6. Side Impact structure

7. All members transferring load from driver restraint system to members

B. Percy

Percy is the basic perspective of seating location for the occupant. Therefore, the 95th male percentile, or 5 percent female percentile, is the one significant step towards phase design. Driver seating positions may be natural or limited according to criteria such as comfort, timing of the egress, angle of view, handling. Percy's minimum requirements are also set in keeping with the laws set out in the rulebook.

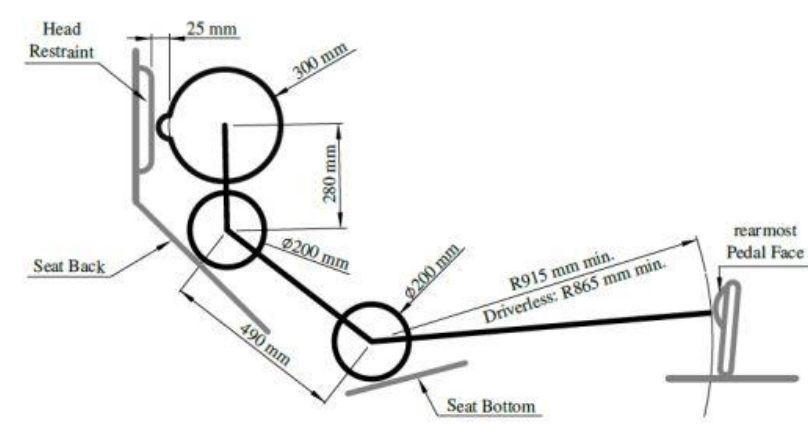

Figure 2: Percy

\section{Cockpit Dimensions}

The 2 cockpit models used to calculate the cell area of the driver. One is inserted vertically from top up to upper member side-impact. One is mounted from the pedal assembly horizontally past the steering wheel, up to 100 $\mathrm{mm}$.
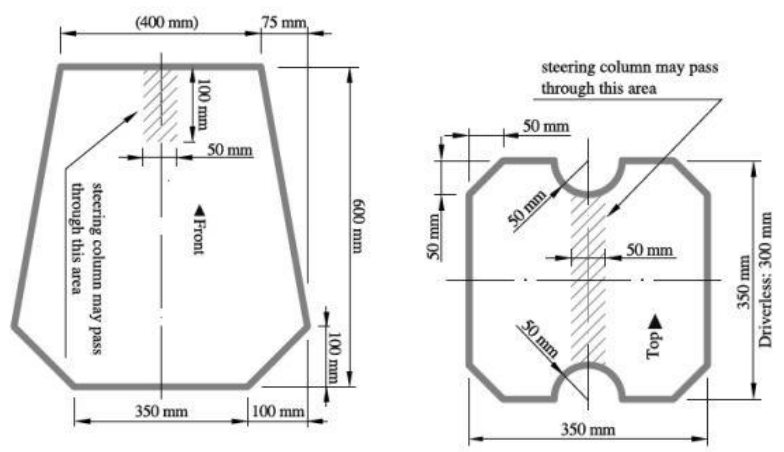

Figure 3: Cockpit Templates

\section{CAD MODELLING}

The chassis was designed using the 3D modeling software SOLIDWORKS. With the past years designs, experiences and requirements various designs were prepared to obtain a design shown below on the basis of the results obtained on static analysis for Von Mises stress, stress flow and maximum deformation. The chassis designed is required to have a high stiffness and light weight to resist the load transfers during acceleration \& breaking.

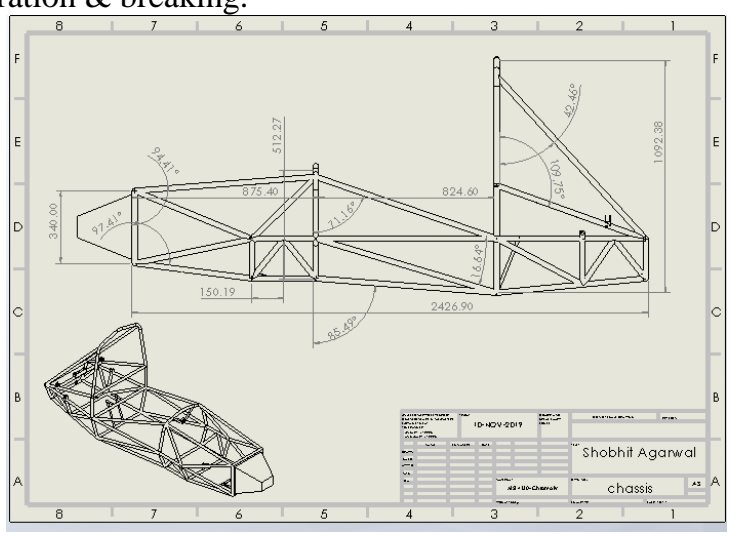

Figure 4: CAD Model of Chassis for AR20

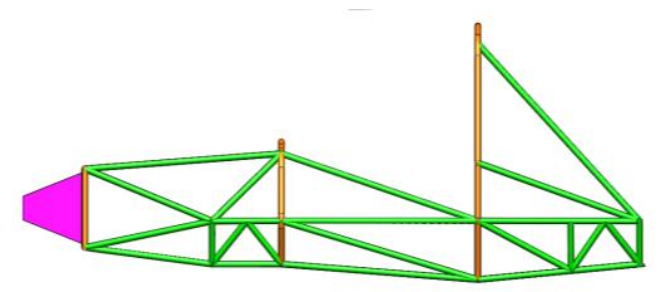

Figure 5: Side View of Chassis for AR20

\section{MATERIAL SELECTION}

The material selected for the chassis is AISI 4130 i.e. alloy steel contains chromium and molybdenum as strengthening agents. It has low carbon content and can be welded easily. The chemical composition of AISI 4130 alloy steel is listed in the following table:

\begin{tabular}{|l|l|}
\multicolumn{1}{|c|}{ TABLE 1} \\
\hline \multicolumn{1}{|c|}{ Clement } & \multicolumn{1}{c|}{ Content $\mathbf{( \% )}$} \\
\hline Iron, Fe & $97.03-98.22$ \\
\hline $\begin{array}{l}\text { Chromium, } \\
\text { Cr }\end{array}$ & $0.80-1.10$ \\
\hline $\begin{array}{l}\text { Manganese, } \\
\text { Mn }\end{array}$ & $0.40-0.60$ \\
\hline Carbon, C & $0.280-0.330$ \\
\hline Silicon, Si & $0.15-0.30$ \\
\hline $\begin{array}{l}\text { Molybdenum, } \\
\text { Mo }\end{array}$ & $0.15-0.25$ \\
\hline Sulfur,S & 0.040 \\
\hline Phosphorus, P & 0.035 \\
\hline
\end{tabular}

The mechanical composition of AISI 4130 alloy steel is listed in the following table:

TABLE 2

\begin{tabular}{|l|c|}
\hline Properties & Metric \\
\hline $\begin{array}{l}\text { Tensile Strength, } \\
\text { Ultimate }\end{array}$ & $560 \mathrm{MPa}$ \\
\hline Tensile Strength, Yield & $460 \mathrm{MPa}$ \\
\hline Modulus of Elasticity & $190-210 \mathrm{GPa}$ \\
\hline Bulk Modulus & $140 \mathrm{GPa}$ \\
\hline
\end{tabular}




\begin{tabular}{|l|c|}
\hline Poisson's Ratio & $0.27-0.30$ \\
\hline BHN & 217 \\
\hline Thermal Conductivity & $42.7 \mathrm{~W} / \mathrm{mK}$ \\
\hline
\end{tabular}

\section{STATIC DATA}

\section{A. Static Loads \& boundry conditions}

The parameters of the vehicle used for the calculation of forces for the static analysis are:

- $\quad$ Mass of the Car and Driver $=320 \mathrm{~kg}$

- Weight Distribution $=40 / 60$

- Height of Center of gravity $=310 \mathrm{~mm}$

- Wheelbase $=1550 \mathrm{~mm}$

- $\quad$ Track Width Front $=1250 \mathrm{~mm}$

- $\quad$ Track Width Rear $=1250 \mathrm{~mm}$

- $\quad$ Deceleration $=1.8 \mathrm{gs}$

- $\quad$ Lateral Acceleration $=2 \mathrm{gs}$

- $\quad$ Longitudinal Acceleration $=0.9 \mathrm{gs}$

\section{CONCLUSION}

The chassis group is extremely pleased with the final design. The team knew that it was time to stop due to both time constraints and the finalization of other sub-groups. As the suspension, ergonomics, and powertrain groups finalize their designs, the chassis group has less room to change things on a large scale. If we did, this would impact other teams and affect their final designs. The final metric table with theoretical values can be seen below:

\section{TABLE 3}

\begin{tabular}{|c|c|c|}
\hline Metric & Units & Theoretical \\
\hline $\begin{array}{c}\text { Torsional Rigidity } \\
\text { (front) }\end{array}$ & ft-lb/deg & 1763 \\
\hline $\begin{array}{c}\text { Torsional Rigidity } \\
\text { (back) }\end{array}$ & ft-lb/deg & 1923 \\
\hline $\begin{array}{c}\text { Bending Stiffness } \\
\text { (front) }\end{array}$ & lbs/in & 4487 \\
\hline $\begin{array}{c}\text { Bending Stiffness } \\
\text { (back) }\end{array}$ & lbs/in & 6782 \\
\hline $\begin{array}{c}\text { Weight } \\
\text { Weight }\end{array}$ & lbs & $45 \mathrm{~F} \mathrm{55R}$ \\
\hline Distribution & in & 10.75 \\
\hline $\begin{array}{c}\text { Vertical Location } \\
\text { of CG }\end{array}$ & & \\
\hline
\end{tabular}

\section{A. Static Analysis Result}

\section{$\boxminus$ Displacement}

$\boxminus$ Total
$[\mathrm{mm}] 0$
 0.5559

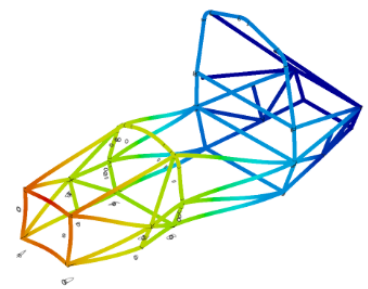

Figure 6: Maximum Deformation in chassis

\section{REFERENCES}

[11] A. Sethi, "Wet sump design for an FSAE racing car," in Applied Mechanics and Materials, 2012.

[12] A. Mutha, S. Thosar, and N. Ghodmare, "Design and optimization of a steering knuckle of FSAE car," Lect. Notes Mech. Eng., 2017. 